\title{
Gene therapy with urokinase-type plasminogen activator regenerates liver tissue
}

\author{
Ana Sandoval-Rodríguez¹, Alejandra Meza-Ríos², Mayra Mena-Enríquez³ and Juan Armendáriz-Borunda1,2* \\ ${ }^{1}$ Department of Molecular Biology and Genomics, Institute of Molecular Biology and Gene Therapy, Universidad de Guadalajara, Guadalajara, \\ Jalisco; ${ }^{2}$ School of Medicine and Health Sciences, Tecnológico de Monterrey, Guadalajara, Jalisco; ${ }^{3}$ Department of Health Sciences, CU Tonalá, \\ Universidad de Guadalajara, Jalisco. Mexico
}

\begin{abstract}
Background and objectives: Gene therapy using urokinase-type plasminogen activator (uPA) has been shown to induce extracellular matrix degradation, hepatocyte proliferation and liver tissue function restoration in liver cirrhosis models. Physiologically, UPA activates plasminogen conversion to plasmin, which leads, depending on the organ, to thrombolysis or extracellular matrix degradation. The purpose of this study was to compare the regenerative effect of gene therapy with adenoviruses encoding wild-type UPA (huPA), as well as its truncated isoform (

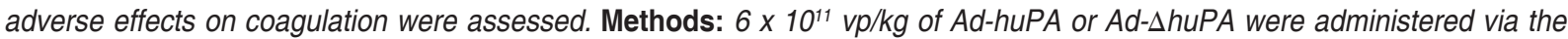
iliac vein to healthy male Wistar rats or to male Wistar rats with cirrhosis induced by chronic poisoning with carbon tetrachloride $\left(\mathrm{CCl}_{4}\right)$. The animals were sacrificed at day 2, 4 or 6 post-treatment. Liver fibrosis, proliferating cell nuclear antigen expression, alanine aminotransferase (ALT) and aspartate aminotransferase (AST) serum levels and coagulation markers were evaluated. Results: On day 6 post-treatment, a fibrosis reversal of $48.7-41.5 \%$ was achieved. AST and ALT levels did not change in cirrhotic animals treated with $\triangle$ huPA, but showed an elevation in healthy animals. Cell proliferation increased in healthy and cirrhotic animals with both transgene isoforms. No coagulation adverse effects were observed in the $\triangle$ huPA group, and by day 6, they had disappeared in the huPA group. Conclusions: Gene therapy with Ad-huPA and Ad-AhuPA favors cell proliferation in cirrhotic animals, without important side effects.
\end{abstract}

KEY WORDS: Gene therapy. Adenovirus. Urokinase-type plasminogen. Cirrhosis.

\section{La terapia génica con el activador de plasminógeno tipo urocinasa media la regeneración hepática}

\section{Resumen}

Antecedentes y objetivos: La terapia génica empleando el activador de plasminógeno tipo urocinasa (huPA) ha demostrado que induce la degradación de matriz extracelular, la proliferación de hepatocitos y el restablecimiento de la funcionalidad tisular en modelos de cirrosis hepática. Fisiológicamente, el uPA activa la conversión del plasminógeno en plasmina, lo que conlleva, dependiendo del órgano, una trombólisis o a degradación de la matriz extracelular. El objetivo de este estudio fue comparar el efecto regenerador de la terapia génica con adenovirus codificando la forma silvestre (huPA), así como su isoforma truncada ( $\triangle$ huPA) en animales sanos y cirróticos. Además, se valoraron los posibles efectos adversos sobre la coagulación. Métodos: Se administró $6 \times 10^{11} \mathrm{pv} / \mathrm{kg}$ del Ad-huPA o Ad-AhuPA a ratas Wistar macho sanas o con cirrosis por intoxicación crónica con tetracloruro de carbono $\left(\mathrm{CCl}_{4}\right)$ vía vena ilíaca. El sacrificio fue al día 2,4 o 6 postratamiento. Se evaluó la fibrosis hepática, la expresión de antígeno nuclear de proliferación celular y niveles séricos

Correspondencia:

*Juan Armendáriz-Borunda

E-mail: armendbo@ @ucs.udg.mx

0016-3813/@ 2021 Academia Nacional de Medicina de México, A.C.. Published by Permanyer. This is an open access article under the CC BY-NC-ND license (http://creativecommons.org/licenses/by-nc-nd/4.0/).
Fecha de recepción: 16-07-2021

Fecha de aceptación: 10-08-2021

DOI: 10.24875/GMM.M21000606
Gac Med Mex. 2021;157:508-515

Disponible en PubMed

www.gacetamedicademexico.com 
de alanina aminotransferasa (ALT) y aspartato aminotransferasa (AST), y marcadores de coagulación. Resultados: Al día 6 postratamiento se alcanzó una reversión de fibrosis del 48.7-41.5\%. Los niveles de AST y ALT no cambiaron en animales cirróticos tratados con $\triangle$ huPA, pero aumentaron en animales sanos comparados con el control sano no tratado. La proliferación aumenta en animales sanos y cirróticos con ambas isoformas del transgén. No se observaron efectos adversos en la coagulación en el grupo $\triangle$ huPA y para el día 6 habian desaparecido en el grupo huPA. Conclusiones: La te-

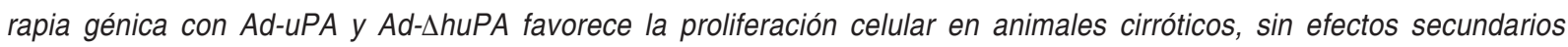
importantes.

PALABRAS CLAVE: Terapia génica. Adenovirus. Plasminógeno tipo urocinasa. Cirrosis.

\section{Introduction}

Liver fibrosis and cirrhosis constitute the common final course of several liver diseases. Caused by several etiologies, liver fibrosis and cirrhosis represent one of the leading causes of morbidity and mortality in the world. In Mexico, liver diseases are among the leading causes of death at productive ages. Fibrosis is the result of an excessive accumulation of extracellular matrix (ECM) components such as collagen and fibronectin, secreted by myofibroblasts in response to chronic cell damage. ${ }^{1}$ The inflammatory response can perpetuate and finally favor the fibrotic process and lead to a pathological state with liver function loss and permanent scar formation. ${ }^{2}$

Plasminogen is a glycoprotein that circulates in plasma as a zymogen that is an inactive plasmin precursor. ${ }^{3}$ Plasmin is a protease that cleaves several ECM proteins, including fibronectin, von Willebrand factor, laminin, thrombospondin and type IV collagen. It plays an important role in the activation of several extracellular matrix metalloproteinases (MMP) such as pro-MMP-1, pro-MMP-3, pro-MMP-9 and pro-MMP-2, which degrade other MEC constituents. ${ }^{4,5}$ Plasmin can affect the activity of cytokines and growth factors, such as transforming growth factor beta, which directly or indirectly influences on extracellular matrix composition and degradation, and is the main pro-fibrogenic cytokine. $^{4}$

Anti-fibrotic therapies have the purpose to inhibit the deposition of ECM proteins and/or to accelerate their degradation. Based on the above, gene therapy using huPA and $\triangle$ huPA genes has been shown to be effective as ant-ifibrogenic therapy in experimental models of liver cirrhosis. Previous studies by our group and others have shown that huPA and $\triangle$ huPA $^{6,7}$ stimulate liver proliferation in cirrhotic models, favoring the restoration of tissue functionality. The purpose of this work was to compare the effect of huPA and $\triangle$ huPA on both cirrhotic and healthy livers and on cell regeneration markers, as well as on the degree of fibrosis and liver function, and to evaluate whether treatment with huPA has adverse effects on coagulation.

\section{Material and methods}

\section{Animal model and treatment administration}

Male Wistar rats ( $\mathrm{n}=5$ /group, $\sim 120$-g weight) were poisoned with carbon tetrachloride $\left(\mathrm{CCl}_{4}\right)$ by the i.p. route for eight weeks. A group of five non-poisoned rats served as healthy control. Healthy and cirrhotic animals were administered $6 \times 10^{11} \mathrm{vp} / \mathrm{kg}$ of Ad-huPA or Ad- $\Delta$ huPA via the iliac vein at the conclusion of the $\mathrm{CCl}_{4}$-poisoning regimen. The adenovectors were titrated as previously described. ${ }^{7,8}$ Sacrifice was carried out on day 2, 4 or 6 post-treatment. Representative sections of all five liver lobes were collected and kept frozen $\left(-70^{\circ} \mathrm{C}\right)$ until their analysis. During the procedures, the rats received care in accordance with Official Mexican Standard NOM-062-ZOO-1999.

\section{Determination of the degree of fibrosis}

To evaluate the degree of liver fibrosis, liver tissue was extracted and fixed in 10\% paraformaldehyde, followed by dehydration on ethanol, and was embedded in paraffin. $5 \mu \mathrm{m}$-thick sections were stained with Masson's trichrome stain. The percentage of fibrosis was determined in 30 random fields using an image analyzer (Image-ProPlus 6.0).

\section{Determination of cell proliferation by immunohistochemistry against PCNA}

Cell proliferation was determined by immunohistochemistry against proliferating cell nuclear 
antigen (PCNA). Liver sections were incubated overnight with monoclonal antibody against PCNA diluted at 1:200 in saline phosphate buffer. Development was carried out with a secondary peroxidase-labeled rabbit polyclonal antibody targeting mouse immunoglobulins and with diaminobenzidine. The samples were counterstained with hematoxylin. Percent reactivity to PCNA was determined in 15 photomicrographs using a computer-assisted image analyzer (Image-ProPlus 6.0).

\section{Liver function tests and coagulation markers}

Under anesthesia, intracardiac puncture was performed on the animals in order for blood to be collected in tubes with ethylenediaminetetraacetic acid and free of anticoagulant; serum and plasma were separated and stored at $-70{ }^{\circ} \mathrm{C}$ until their use. Serum levels of alanine aminotransferase (ALT) and aspartate aminotransferase (AST), as well as plasma fibrinogen, prothrombin time (PT) and partial thromboplastin time (PTT), were determined on a Vitros DT 60 automated analyzer.

\section{Statistical analysis}

Data are presented as the mean \pm standard deviation (SD) for graphical representations. Statistical significance was determined by one-way ANOVA; the differences between two groups were analyzed with Student's t-test. Data were analyzed with Graph Prism 7.0 software. A degree of significance $(p)<0.05$ was considered statistically significant.

\section{Results}

\section{Gene therapy with Ad-huPA and Ad- $\triangle$ huPA reverses liver fibrosis}

Ad-huPA and Ad- $\triangle$ huPA administration reverses fibrotic tissue by between $48.7 \%-41.5 \%$, with the highest effect being reached at day 6 post-treatment (Fig. 1). No significant differences were observed in anti-fibrotic effect between the transgenes on any of the evaluated days. However, livers treated with $\triangle$ huPA exhibit less lobular and periportal fibrosis, as well as a decrease in the width of the fibers and in histological alteration of the tissue as days after treatment advance (day 4 and 6) in comparison with controls.

\section{Liver function tests}

Figure 2 shows the levels of liver enzymes ALT and AST, which were determined in order to assess the liver function and which significantly increased after administration of the adenovectors both in healthy controls and in cirrhotic animals, with both forms of the transgene. This increase could be due to the cytotoxic effect of adenovirus on liver tissue, which is present even in healthy livers. In this consideration, the cirrhotic rats treated with $\triangle \mathrm{UPA}$ showed ALT and AST lower levels than the cirrhotic rats treated with uPA (Fig. 2), which can be interpreted as an indirect measure of the benefits on the liver function that the treatment with $\triangle \mathrm{UPA}$ achieves in cirrhotic livers.

\section{Ad-AhuPA does not alter coagulation markers}

In cirrhotic animals treated with $\triangle$ huPA, PT, PTT and fibrinogen values did not increase in comparison with control animals, which indicates that there were no adverse effects caused by transgenesis, while Ad-huPA therapy modified said markers by day 4 vs. controls (Fig. 3 ). These results suggest alterations in the coagulation cascade caused by wild UPA within the first days after treatment.

\section{Treatment with huPA and $\triangle$ huPA favors cell proliferation in the liver}

PCNA staining in normal tissue hepatocytes was $53 \%$ with uPA and $50 \%$ with $\triangle$ huPA at day 6 post-treatment (Fig. 4). On the other hand, cirrhotic livers showed a $61 \%$ increase in cell regeneration after treatment with wild-type huPA and $69 \%$ with truncated huPA, in comparison with untreated animals (Fig. 4). PCNA-positive cells were identified as hepatocytes predominantly on day 4 and 6 post-treatment, with a significant difference for $\triangle$ huPA only on day 6 .

\section{Discussion}

In this study, we demonstrated that Ad-huPA and Ad- $\triangle$ huPA systemic administration reverses fibrosis 
$\mathbf{A}$

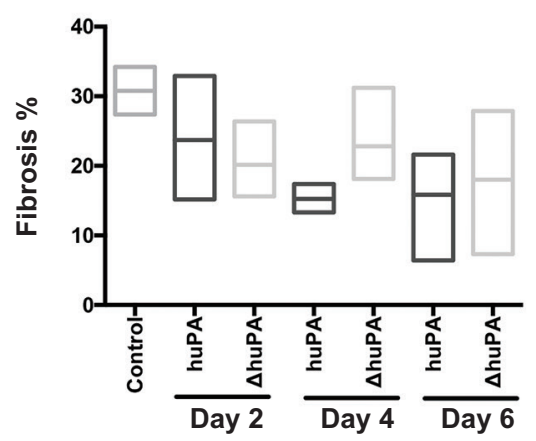

B

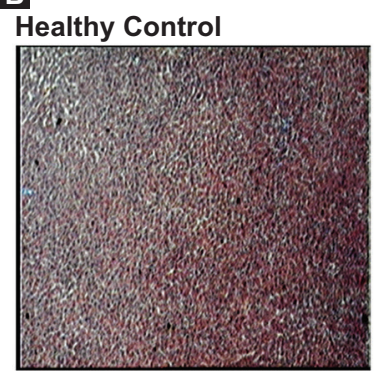

Healthy + Ad

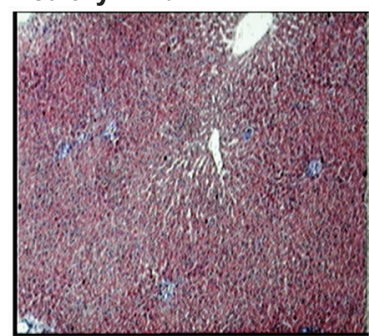

Cirrhotic Control

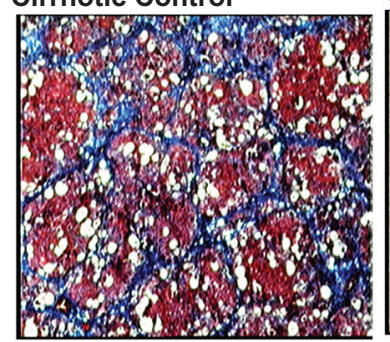

Ad-huPA

2D

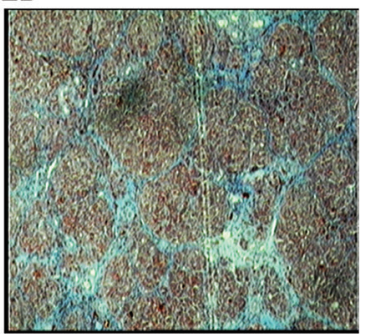

4D

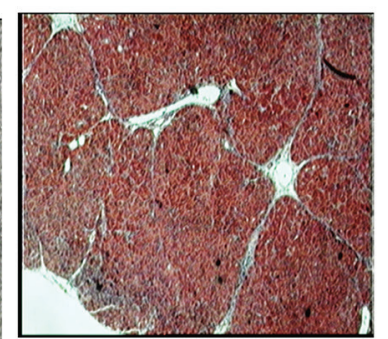

6D

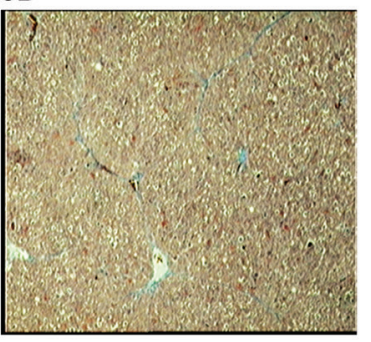

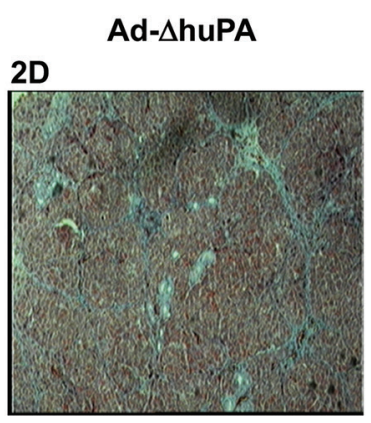

4D

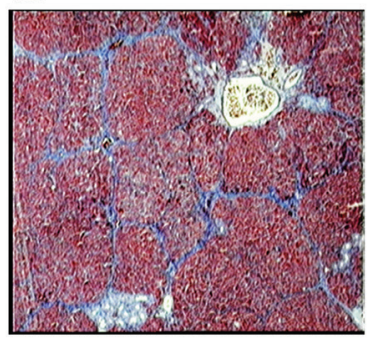

6D

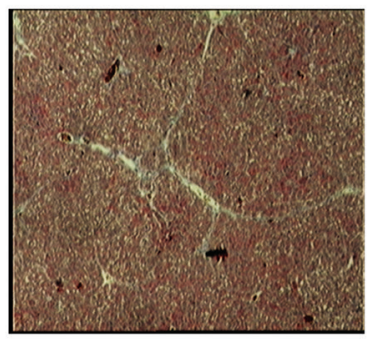

Figure 1. Percentage of fibrosis in liver tissue after treatment with Ad-huPA or Ad-AhuPA adenoviral vectors. A: percentage of liver fibrosis at post-treatment day 2, 4 and 6. The largest decrease in fibrotic tissue was observed at day 6 with both transgenes. No significant differences are observed in fibrosis reversal between both transgenes. B: representative photographs of liver samples stained with Masson's trichrome stain (20X). On first column, healthy liver controls and healthy livers treated with viral vector show a predominance of parenchymal components. Control cirrhotic tissue exhibits characteristic cirrhotic nodules surrounded by thick fibrosis bands that show blue-stained progressive fibrosis. On second and third column, livers of animals treated with Ad-huPA and Ad- $\triangle$ huPA, respectively; on both columns, after 6 days of treatment with huPA or $\triangle$ huPA, there are only thin fibrosis bands extending from portal areas, as well as less tissue deformation and mild central vein sclerosis. huPA: urokinase-type plasminogen activator wild form; $\triangle$ huPA: urokinase-type plasminogen activator truncated isoform.

in an experimental cirrhosis model at levels that are comparable to those obtained in previous publications using Ad-huPA or Ad- $\Delta$ huPA $^{6,7}$. In addition, the results of the morphometric analysis showed no significant differences between the groups treated with the different forms of the transgene. The decrease in fibrous tissue increased over time after the administration of both treatments, with its maximum 

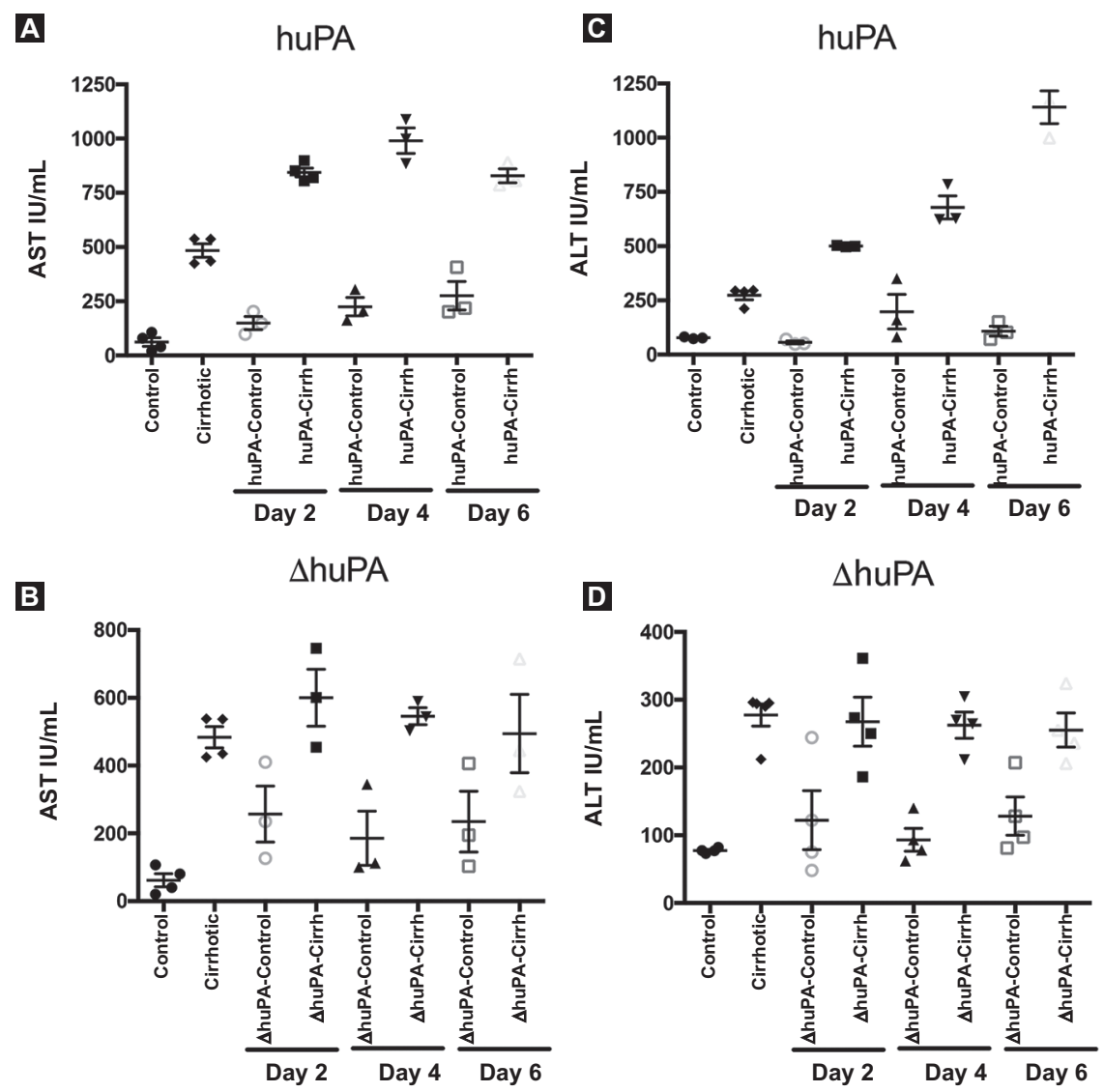

Figure 2. Liver enzymes (ALT and AST) serum levels after Ad-huPA or Ad-AhuPA administration. A and B: AST and ALT levels of controls and animals treated with Ad-huPA at different cutoff times. C and D: graphic representation of AST and ALT levels in the group treated with Ad- $\triangle$ huPA and its controls. After transgenes administration via the iliac vein, serum analyses were carried out at days 2, 4 and 6; baseline values were monitored in the control group without adenovirus administration.

ALT: alanine aminotransferase; AST: aspartate aminotransferase; huPA: urokinase-type plasminogen activator wild form; $\triangle$ huPA: urokinase-type plasminogen activator truncated isoform.

peak being reached at sixth day within a range of 41 to $48 \%$ in fibrosis reduction in comparison with the untreated control group, with statistical difference being reached by day 4 and 6 in the animals treated with huPA and by day 6 in $\triangle$ huPA-treated animals $(p<0.05)$ vs. untreated animals. To corroborate the benefits observed in fibrous tissue reversion, we evaluated cell regeneration in healthy and cirrhotic animals, assuming that the microenvironment conditions present in a damaged liver could favor a higher response in tissue regeneration. The results show that cell regeneration measured by PCNA-targeted immunohistochemistry increases with both treatments in comparison with untreated rats $(p<0.05)$, with maximum peak being reached at day 6 post-treatment. However, cell regeneration did significantly increase $(p<0.05)$ in cirrhotic animals in comparison with normal rats (50 vs. $69 \%$ ). Nevertheless, both huPA and $\triangle$ huPA appear to comparably increase hepatocyte regeneration in cirrhotic animals (Fig. 4). This fact can be explained by previous studies that report the role of tumor necrosis factor alpha (TNF- $\alpha$ ) and interleukin 6 (IL-6) in preparing liver cells for the regeneration process after partial hepatectomy. ${ }^{9,10}$ On the other hand, plasminogen has been shown to mediate UPA reparative properties in the liver; therefore uPA in a cirrhotic liver in combination with the presence of pro-inflammatory cytokines in response to damage may be part of a microenvironment that provides optimal conditions for a better regeneration process than the environment present in healthy liver tissue. ${ }^{11}$ On the other hand, adenoviral vectors are known to have tropism for liver tissue when systemically administered, ${ }^{12}$ 
$\mathbf{A}$

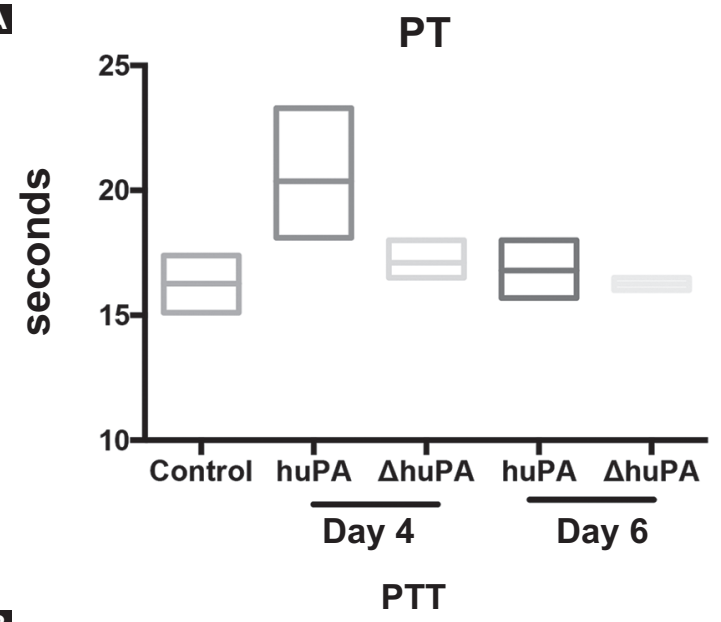

B

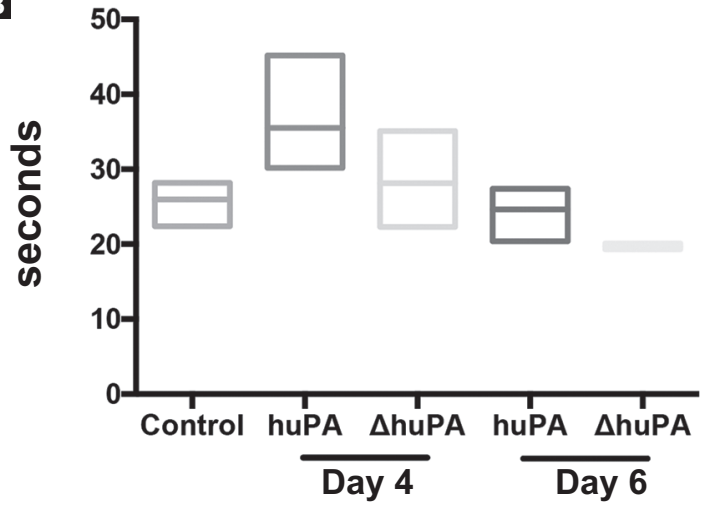

C

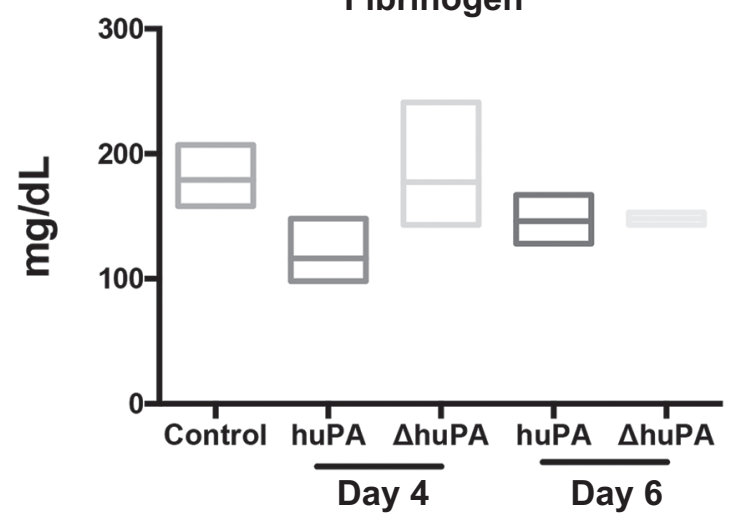

Figure 3. Coagulation markers evaluation. Coagulation markers determination: prothrombin time (PT) (A), partial thromboplastin time (PTT) (B) and fibrinogen (C). Cirrhotic animals treated with Ad-huPA and Ad- $\triangle$ huPA were analyzed. PT, PTT and fibrinogen values did not increase in cirrhotic animals treated with $\triangle U P A$ in comparison with control animals, which indicates that there are no adverse effects caused by transgenesis, whereas Ad-huPA therapy increases coagulation parameters above those of controls, particularly on day 4, which implies a disorder in the coagulation cascade caused by the form of secreted uPA.

huPA: urokinase-type plasminogen activator wild form; $\triangle$ huPA: urokinase-type plasminogen activator truncated isoform; uPA: urokinase-type plasminogen activator. which represents an advantage by reducing possible side effects of UPA expression in other tissues. Previously, our group demonstrated that adenoviruses efficiently target hepatocytes, and that they can safely transduce cirrhotic livers..$^{13}$ In this study, we detected a significant increase of liver enzymes ALT and AST in cirrhotic animals with Ad-huPA treatment, suggesting cellular damage that does not occur with Ad- $\triangle$ huPA treatment. In addition, healthy animals tend to show an increase in liver function tests serum levels with both treatments, but in a less pronounced form after adenoviruses administration. Adenoviruses administration is known to increase TNF- $\alpha$ and IL- 6 serum levels and to likely prolong clotting times; ${ }^{14}$ it is important to note that the animals had liver enzymes elevation during the first $48 \mathrm{~h}$ after adenovirus administration, which decreased at between 72 and $96 \mathrm{~h}$ post-treatment (Fig. 2) in the case of the groups treated with $\triangle$ huPA. Of note, ALT and AST serum levels were lower in the animals treated with Ad- $\triangle$ huPA in comparison with Ad-uPA, which implies a specific effect of the transgene. However, there was no mortality in cirrhotic animals in comparison with healthy rats, which suggests that the transient damage caused by the administration of the vector and the transgene can be resolved without further consequences.

Due to cirrhotic tissue deterioration, animals with liver damage might experience coagulation disorders ${ }^{15}$ which could increase with the administration of huPA as a transgene owing to its role in the coagulation system, ${ }^{3}$ which is why we analyzed the coagulation parameters in order to monitor possible adverse events. Given that $\triangle$ huPA is a non-secreted protein, we expected that its use as a transgene would not cause any alteration in coagulation events. ${ }^{16}$ Neither of the transgene forms negatively affected the coagulation markers that were evaluated, with the differences in fibrinogen, PT and PTT levels for both Ad-huPA and Ad- $\Delta$ huPA groups not showing significant differences between healthy controls and treated cirrhotic rats six days after treatment. Furthermore, at sixth day after treatment, evaluated coagulation markers reached the baseline levels present in healthy untreated animals. 
A

huPA
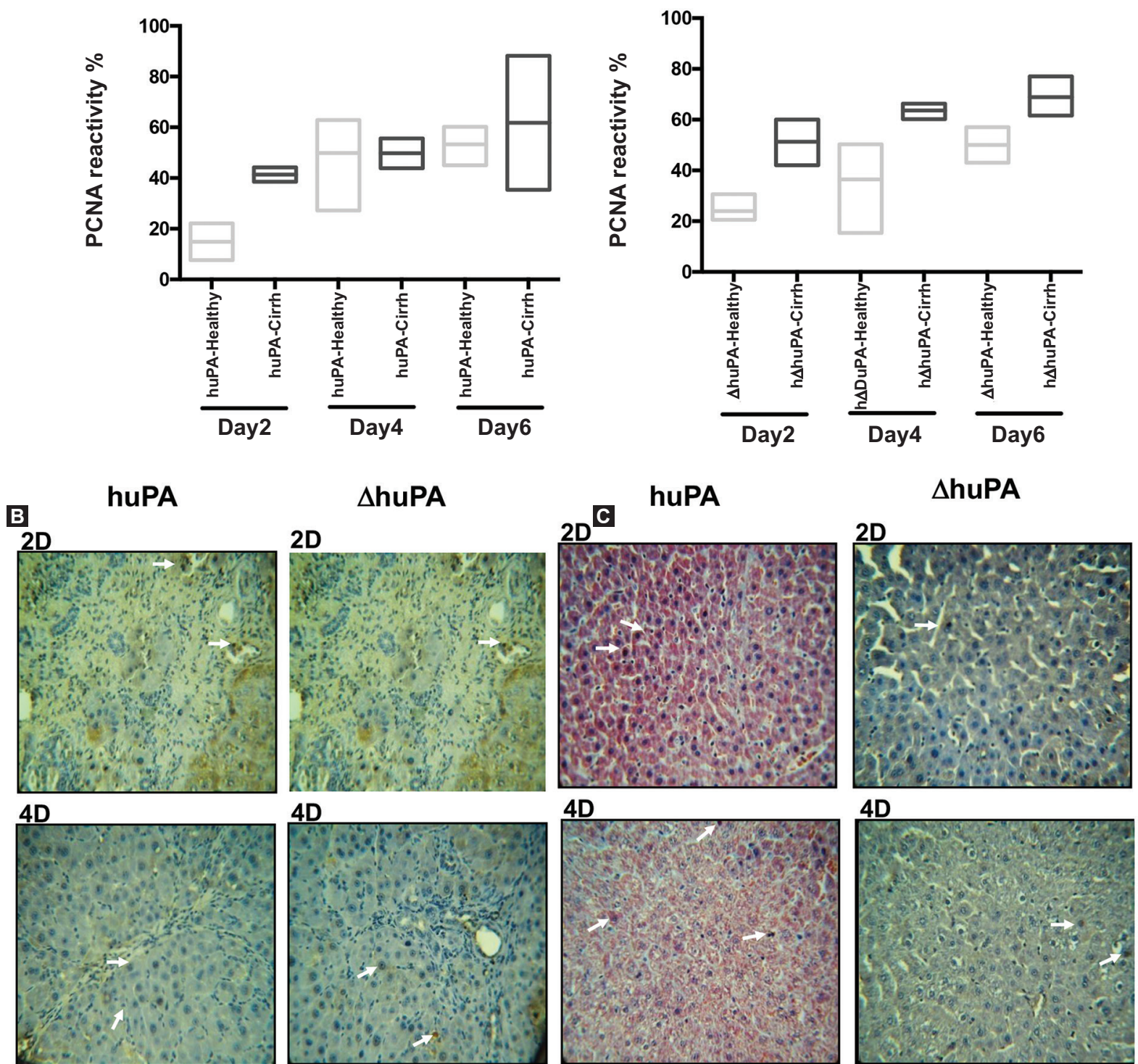

6D

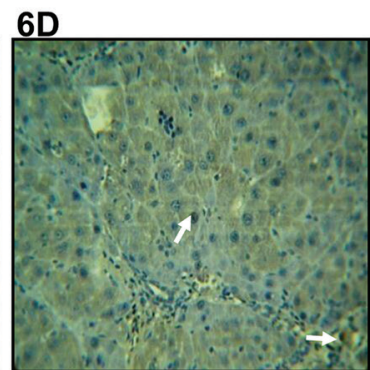

6D
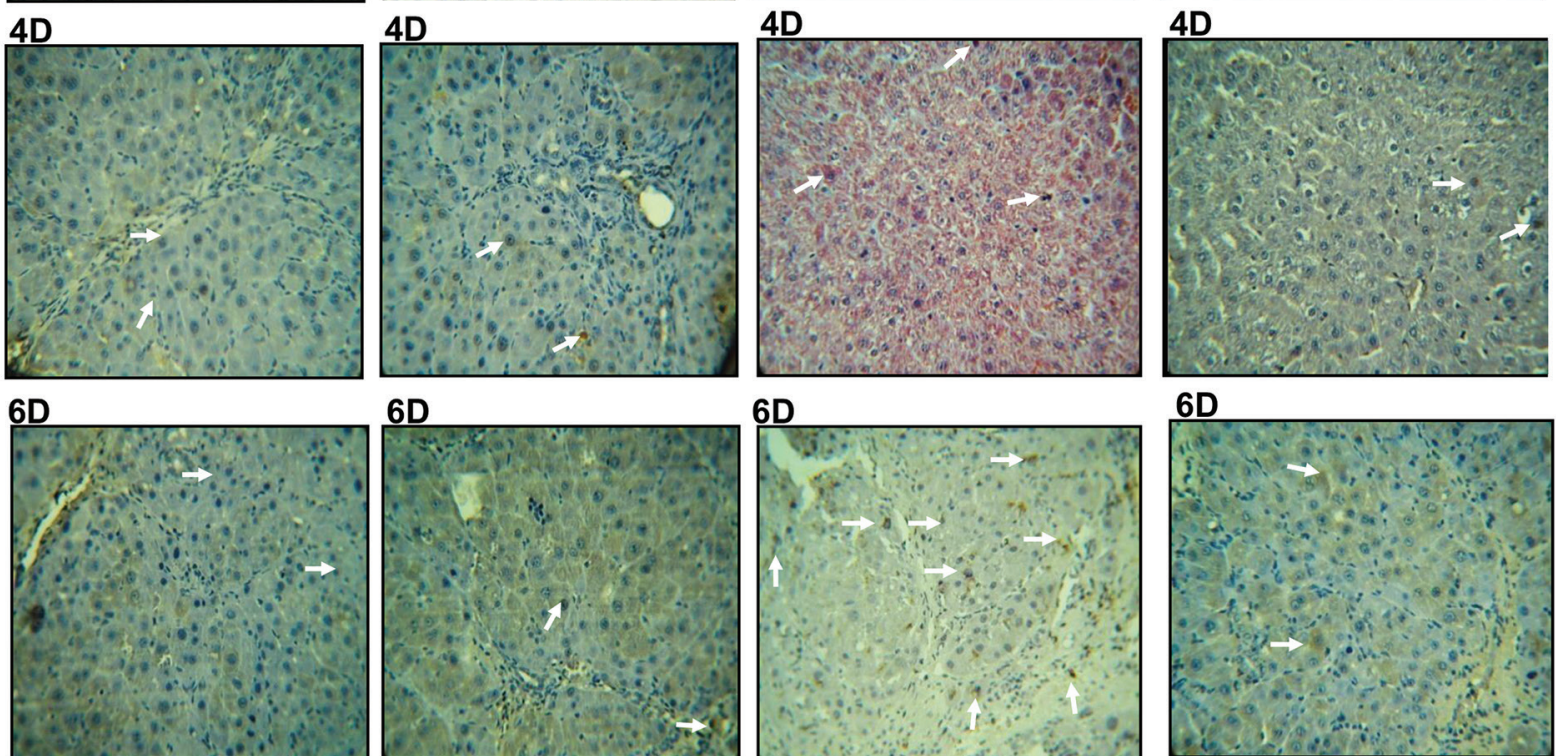

6D

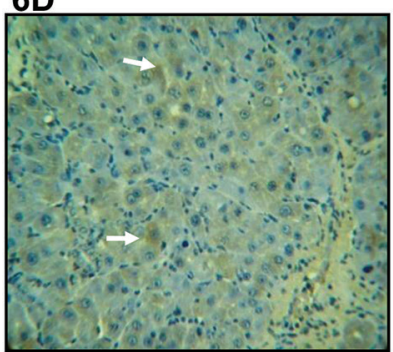

Figure 4. Post-treatment cell proliferation analysis based on cell proliferation nuclear antigen (PCNA) marker. Nuclei on mitosis were quantified by two independent pathologists (40X). A: percentage of hepatocytes stained with PCNA in the different analyzed groups; $50-53 \%$ PCNApositivity is observed in normal hepatocytes on day 6 after adenovirus' administration. B and C: after 6 days of treatment, cirrhotic livers show abundant positively-stained nuclei (white arrows) and mitotic shapes in $60-69 \%(p>0.005)$ in comparison with untreated animals. On B representative photographs, PCNA-positive cells were identified as hepatocytes and predominate on days 4 and 6 after treatment, with a significant difference for $\triangle U P A$ transgene only on day $6(p>0.005)$. Cirrhotic liver sections without adenovirus administration were used as controls. Measurements had a variation of $3 \%$ between the two different pathologists.

$\triangle$ huPA: urokinase-type plasminogen activator truncated isoform. 


\section{Conclusions}

Based on these observed results, it is suggested that transgenesis using huPA or $\triangle$ huPA can be employed as an anti-fibrotic treatment without fear of inducing a severe coagulation disorder, even if administered in cirrhotic animals.

\section{Funding}

This project has no direct funding.

\section{Conflict of interests}

The authors declare that there are no conflicts of interest regarding this publication.

\section{Ethical disclosures}

Protection of human and animal subjects. The authors declare that the procedures that were followed adhered to the ethical standards of the responsible committee for experimentation on human beings and were in agreement with the World Medical Association and the Declaration of Helsinki.

Confidentiality of data. The authors declare that no patient data appear in this article.

Right to privacy and informed consent. The authors declare that no patient data appear in this article.

\section{References}

1. Macías-Barragán J, Sandoval-Rodríguez AS, Navarro-Partida J, Armendariz-Borunda J. The multifaceted role of pirfenidone and its novel targets. Fibrogenesis Tissue Repair. 2010;3:16.

2. Seki E, Brenner DA. Recent advancement of molecular mechanisms of liver fibrosis. J Hepatobiliary Pancreat Sci. 2015;22:512-8.

3. Drixler TA, Vogten JM, Gebbink MFBG, Carmeliet P, Voest EE, Borel Rinkes IHM. Plasminogen mediates liver regeneration and angiogenesis after experimental partial hepatectomy. Br J Surg. 2003:90:1384-90.

4. Herren T, Swaisgood C, Plow EF. Regulation of plasminogen receptors. Front Biosci. 2003;8:d1-8.

5. González-Cuevas J, Bueno-Topete M, Armendáriz-Borunda J. Urokinase plasminogen activator stimulates function of active forms of stromelysin and gelatinases (MMP-2 and MMP-9) in cirrhotic tissue. J Gastroenterol Hepatol. 2006;21:1544-54.

6. Salgado S, Garcia J, Vera J, Siller F, Bueno M, Miranda A, et al. Liver cirrhosis is reverted by urokinase-type plasminogen activator gene therapy. Mol Ther. 2000;2:545-51.

7. Meza-Ríos A, García-Benavides L, García-Bañuelos J, Salazar-Montes A, Armendáriz-Borunda J, Sandoval-Rodríguez A. Simultaneous administration of ADSCs-based therapy and gene therapy using Ad-huPA reduces experimental liver fibrosis. PLoS One. 2016;11:e0166849.

8. Armendáriz-Borunda J, Bastidas-Ramírez BE, Sandoval-Rodríguez A González-Cuevas J, Gómez-Meda B, García-Bañuelos J. Production of first generation adenoviral vectors for preclinical protocols: amplification, purification and functional titration. J Biosci Bioeng. 2011;112:415-21.

9. Streetz K, Luedde T, Manns M, Trautwein C. Interleukin 6 and liver regeneration. Gut. 2000;47:309-12.

10. Campbell JS, Prichard L, Schaper F, Schmitz J, Stephenson-Famy A, Rosenfeld ME, et al. Expression of suppressors of cytokine signaling during liver regeneration. J Clin Invest. 2001;107:1285-92.

11. Shanmukhappa K, Sabla GE, Degen J, Bezerra JA. Urokinase-type plasminogen activator supports liver repair independent of its cellular receptor. BMC Gastroenterol. 2006;6:40.

12. Hendrie PC, Russell DW. Gene targeting with viral vectors. Mol Ther. 2005;12:9-17.

13. García-Bañuelos J, Siller-López F, Miranda A, Aguilar LK, Aguilar-Cordova E, Armendáriz-Borunda J. Cirrhotic rat livers with extensive fibrosis can be safely transduced with clinical-grade adenoviral vectors. Evidence of cirrhosis reversion. Gene Ther. 2002:9:127-34.

14. Smith JS, Tian J, Lozier JN, Byrnes AP. Severe pulmonary pathology after intravenous administration of vectors in cirrhotic rats. Mol Ther. 2004;9:932-41.

15. O'Leary JG, Greenberg CS, Patton HM, Caldwell SH. AGA Clinical practice update: coagulation in cirrhosis. Gastroenterology. 2019;157:34-43.

16. Lieber A, Peeters MJ, Gown A, Perkins J, Kay MA. A modified urokinase plasminogen activator induces liver regeneration without bleeding. Hum Gene Ther. 1995:6:1029-37. 